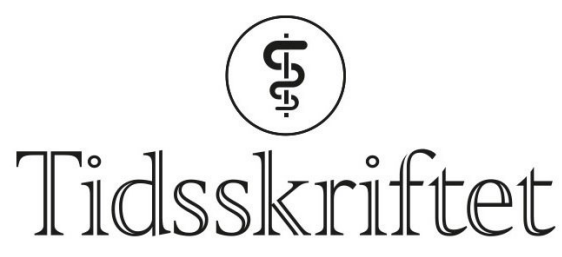

DEN NORSKE LEGEFORENING

\title{
Historier til å lære av
}

MINILEDER

ARE BREAN

Sjefredaktør

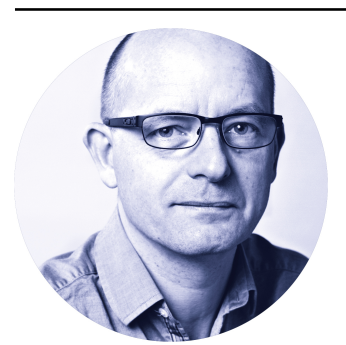

En av verdens eldste medisinske tekster, Edwin Smiths papyrus, inneholder 48 detaljerte kirurgiske kasuistikker. Den ble skrevet rundt år 1600 før vår tidsregning, åpenbart for læringsformål.

I dag, over 3 ooo år senere, rangerer kasuistikker nesten nederst i det medisinske kunnskapshierarkiet. Likevel øker antallet publiserte kasuistikker mer enn antallet systematiske oversiktsartikler. Det er ikke uten grunn. Kasuistikker kan som få andre sjangere bygge en bro av forståelse fra det teoretiske til det praktiske, de kan avsløre nye og uventede sammenhenger og stimulere til nysgjerrighet og læring. Kasuistikker er uvurderlige i undervisning og gir knagger for hukommelsen.

I dette nummer av Tidsskriftet presenterer vi vår nye fagfellevurderte sjanger «Kort kasuistikk». Den skiller seg fra vår andre kasuistikksjanger, «Noe å lære av», ved at den er kortere. Også oppbygningen er ulik: En kort presentasjon av pasienthistorien etterfølges av en kort, poengtert diskusjon. Formatet står på historisk grunn, for slik er også kasuistikkene i Edwin Smiths papyrus bygd opp.

Vår nye sjanger skal gi læring og refleksjon, og forhåpentligvis stimulere deg som leser til å dele lærerike kasuistikker fra egen praksis. Fra det partikulære kan man lære mye, også om det generelle. Det gjelder like mye i dag som for 3 ooo år siden.

Publisert: 17. september 2018. Tidsskr Nor Legeforen. DOI: 10.4045/tidsskr.18.14.01

(C) Tidsskrift for Den norske legeforening 2020. Lastet ned fra tidsskriftet.no 